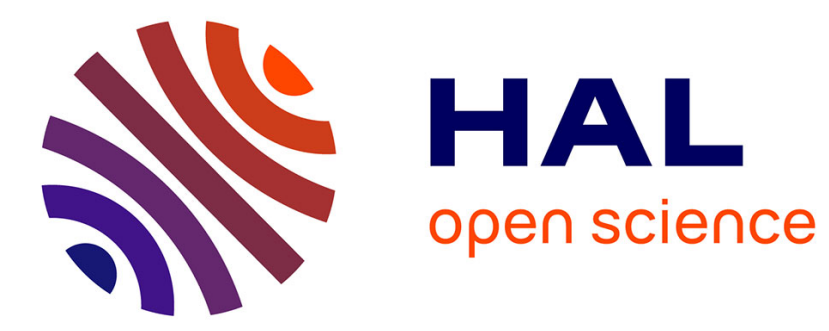

\title{
The Social Dimension of the European Union
}

Monica Threlfall

\section{To cite this version:}

Monica Threlfall. The Social Dimension of the European Union. Global Social Policy, 2007, 7 (3), pp.271-293. 10.1177/1468018107082235 . hal-00571808

\section{HAL Id: hal-00571808 \\ https://hal.science/hal-00571808}

Submitted on 1 Mar 2011

HAL is a multi-disciplinary open access archive for the deposit and dissemination of scientific research documents, whether they are published or not. The documents may come from teaching and research institutions in France or abroad, or from public or private research centers.
L'archive ouverte pluridisciplinaire HAL, est destinée au dépôt et à la diffusion de documents scientifiques de niveau recherche, publiés ou non, émanant des établissements d'enseignement et de recherche français ou étrangers, des laboratoires publics ou privés. 


\title{
The Social Dimension of the European Union
}

Innovative Methods for Advancing Integration

\author{
MONICA THRELFALL \\ Loughborough University, UK
}

\begin{abstract}
AB STRACT Regional integration processes can learn from the particularities of the European Union's social dimension, despite its apparent inconsistencies and sui generis form of development. The article provides a comprehensive retrospective overview of developments, and pays particular attention to the political and technical procedures adopted for progressing social policy. It argues that a regional integration process in a wide range of social fields has developed in the EU despite facing dissent and dilemmas for over 50 years. It claims that the EU now enjoys a working and workable apparatus of policies, practices and laws in a broad social dimension, that are not only far more extensive than first envisaged in the Treaty of Rome, but are also destined to expand further. In particular, the article moves beyond previous accounts in arguing that procedural complexity has been an intrinsic and creative part of the social dimension to European integration.
\end{abstract}

KEYWORDS European Union, integration methods, social policy

\section{Introduction}

Social policy has gained international prominence and it is now considered appropriate for regional groupings of countries to develop cross-border regional redistribution, regulation of the movement of labour, and mechanisms for the articulation of social and labour rights (Yeates and Deacon, 2006: 3). Regionalism provides a constructive alternative to the limitations and problems associated with both the bilateral and global modes of international socio-economic redistribution and provision of rights (Yeates and 
Deacon, 2006: 3). In fact Yeates (2001) holds that social policies both at national and supranational levels are intrinsic to globalization processes and indeed underpin them. Indeed, social policies and welfare issues can become the terrain for contestation by domestic actors, whether voters, consumers or producers, who are seeking to regulate or oppose globalizing strategies (Yeates, 2002). Thus social policy can be argued to be truly functional to a regional integration process in the era of globalization, coexisting and co-evolving with it (Vobruba, 2005: 85). And the counter-argument - that the global market system and the EU's response to it have increasingly constrained and circumscribed national welfare states (Leibfried, 2005: 273) - only serves to highlight the need to understand the environment in which these can progress. In this context, regional integration processes can certainly draw on each other's experiences, and those of the EU are highly revealing.

Yet, the EU's social dimension often appears to be something of a conundrum. On the one hand it is a set of binding regulations, part of the EU acquis communautaire - the entire body of EU legislation that all new member states must apply in order to join. On the other, it also consists of 'soft' law, ${ }^{1}$ merely exhortative measures such as recommendations, declarations of intent, and guidelines. And since we know that social policy concerns education, health and welfare, it is puzzling to find most policy instruments concern working conditions instead. EU membership involves agreeing to supra-national pooling of policy and resources, yet states are still free to decide on social expenditure budgets and impose cuts to social services if they wish. European political discourse can give the impression that the social dimension is largely an abandoned project, yet new measures get adopted.

These common perceptions of the contradictions surrounding this field arise both from the substance and reach of policies and from the methods through which they are adopted. This article seeks to dispel some of the apparent inconsistencies through a comprehensive retrospective overview of developments, and by paying particular attention to the political and technical procedures adopted for progressing social policy, since these help explain its continued reinforcement. It argues that a regional integration process in a wide range of social fields has developed in the EU despite facing obstacles and dissent for over 50 years. It claims that the EU now enjoys a working and workable apparatus of policies, practices and laws in a broad social dimension, that are not only far more extensive than first envisaged in the Treaty of Rome, but are also destined to expand further. In particular, the article moves beyond previous accounts in arguing that procedural complexity has been an intrinsic and creative part of the social dimension to European integration, rather than an indication of its failure.

In particular, the building of the EU's social dimension signals that when political consensus over social fields has failed to materialize with the use of the 'traditional Community method' (Wallace, 2005: 86), innovative routes can be essayed that engage a variety of political actors in a continual search for 
effective ways to advance integration. While this may be common in political negotiations in general, the way this occurs in EU social policy making is not well mapped nor understood. While acknowledging that there are several valid disciplinary approaches for discussing this field, the article aims to bridge the gaps that arise when academic traditions of analysis pertaining to social policy, industrial relations, politics or legal scholarship are applied on their own.

As to parameters and definitions, the article neither sets out to trace the intergovernmental politics of social integration nor to explain why political decisions are made, but to focus on the bow question, tracing the cumulative competencies acquired by European institutions, in the main, the Commission and Council. ${ }^{2}$ It adopts an inclusive view of the 'social dimension' to include EU governance arrangements in the fields of labour relations and working conditions, employment, social protection, education, healthcare, free movement, fundamental social rights, and combating a wide range of social inequalities and discriminations to benefit $\mathrm{EU}$ nationals and established residents. In turn, 'social policies' are taken to be the specific intergovernmental or supranational decisions taken by the member states within the wider social dimension of EU-level activities. Such policies can include the Structural Funds because they are designed to achieve economic convergence across borders by funding only disadvantaged regions from the whole EU territory, and can be regarded as a social redistributive arm of the EU, particularly when they provide support for poor agricultural communities, invest in declining industrial areas, or offer training programmes for the unemployed and women returners, among others. While space does not allow policies in all fields to be charted, the account presents a broad range of developments and policies. As to 'social integration', the article follows Threlfall (2003) in understanding that social integration is a process that runs parallel to economic and political integration in the $\mathrm{EU}$, as in any regional integration process. When analysed from a citizen's or user's perspective, social integration is the result of processes of harmonization of legal environments, of specific approximation of laws and practices, of convergence in policies and practices, and convergence in social trends (outcomes). These contribute in varying degrees to allowing citizens to experience living in the $\mathrm{EU}$ as if in a single country.

\section{Development of the Social Dimension of European Integration}

Within this general frame, the article seeks first to characterize the EU's social dimension in terms of the competencies that $\mathrm{EU}$ institutions have gained in social policy fields. Second, it seeks to explain such growth by focusing on the plurality of methods and routes for decision-making that have been deployed in order to advance integration in one or other of its manifestations. It argues 
that the social facet of integration is broader, deeper and more diverse than it appears to be from some other accounts, and that multi-level modes of governance have had to be set in train in order to overcome or bypass resistance (at veto points) and even blocking by member states (veto players). In a third section, it is argued that the European Constitution containing the Charter of Fundamental Rights augur further binding as well as exhortative legal integration of member states in new areas that widely overstep the boundaries of the original European Economic Community's social goals. The article ends by reflecting on whether the development of the EU in this regard holds any useful pointers for other regional integration processes.

\section{UNEVEN EXPANSION OF COMMUNITY COMPETENCIES AND DEEPENING OVER TIME}

The development of the social dimension is complex and multilayered. It has lacked both the political imperatives to integration that have given the whole European project its historic impulse, and the economic incentives that have spawned the single market and the euro-zone. Instead, it is commonly thought that social policy development is restrained by national governments eager to retain control over welfare provision and social expenditure budgets in their ongoing bids to gain and retain the support of their electorates.

Yet looking back over nearly five decades, a number of critics recognize that there has been a fundamental expansion of the social dimension of European integration (e.g. Geyer, 2000; Hantrais, 2000; Kleinman, 2002). A significant set of powers has been transferred to the supra-national level (Leibfried and Pierson, 1995), particularly with regard to the physical working environment of employees and the equal treatment at work of different categories of workers. As to workers having a say in the management of their companies, both labour and business actors are involved in a 'corporatist policy community' (Falkner, 1998). By the late 1990s, a lasting consensus between member states had been achieved around a fairly extensive corpus of shared employmentfocused regulation. Furthermore, the EU's 'workerist' focus had become more 'welfarist' (Threlfall, 2002). By the new millennium, a new welfare space had opened up, containing a 'patchwork of interventions' (De Búrca, 2005: 7). In particular, with the extension of the Open Method of Coordination beyond employment, the member states engage in an array of simultaneous and interlocking cooperation and mutual surveillance processes (Goetschy, 2002), covering poverty reduction (social inclusion), education, training, pensions, and job creation, among others. Through these, the EU is building a 'still fragmented' but 'distinctive EU welfare dimension' (De Búrca, 2005: 1). In addition, social integration has progressed through convergence of policies, policy outcomes and social trends, as well as through harmonization and approximation of laws, to the point where a series of 'single social areas' have been created in which citizens experience living or working in the EU as if they were in a single country (Threlfall, 2003). 
KEY DEVELOPMENTS IN THE 1957-90 PERIOD

Part 1 of the 1957 Treaty of Rome entitled 'Principles' manifested the nascent Community's commitments to maintaining a high level of social protection for workers, increasing standards of living, quality of life and improving living conditions, indicating there was a basis for a social dimension to the European Community (EC) from the start. Yet the short 'Part 3, Title III on Social Policy' of the Treaty did not in fact provide a clear legal basis for any initiatives connected with welfare matters. Article 118 listed the fields for which the Commission was merely to promote 'close collaboration' between member states as: '-employment -labour law and working conditions; -vocational training; social security; -prevention of occupational accidents and diseases; -occupational hygiene; -the right of association, and collective bargaining between employers and workers'. Social security was the only term associated with welfare, and this turned out to refer mainly to intra-EU migrant workers. Nonetheless, there was a basis for social policy regarding labour matters.

Until the mid-1970s the Council of Ministers adopted virtually no 'legal instruments' - legally valid, though not necessarily binding, decisions - to develop the Commission's role in any areas of social policy except facilitating the free movement of workers (for an early account, see Shanks, 1977). It took pressure from the women's movement for the EC to implement the Treaty Article 19 on equal pay, and for the 1975 and 1976 sex equality directives to be adopted (Hoskyns, 1996). They heralded the effective start of social regulation in the EU.

When Commission President Jacques Delors articulated his vision of a greater social dimension in the mid-1980s, the pace of policy making changed (Ross, 1995). Claiming the need for guiding social principles, Delors persuaded most member states in 1989 to adopt a 'Community Charter of Fundamental Rights of Workers', though it was rejected by the UK (for contemporary British views see European Parliament British Labour Group, 1989; Grahl and Teague, 1992; Hughes, 1991; Labour Research Department, 1989). The Charter proposed that the Community should concern itself with the well-being of people in general - the elderly, the young, the excluded adding new rights for male and female workers already in the labour market, though not for women as a gender. The Commission (1989) launched the first of a number of Social Action Programmes and by the early 1990s, a fairly substantial social dimension of European regulation had developed, strong on providing workers with a safe and healthy working environment and on defending sex equality, but rather weaker on job protection. Yet the mutual recognition of social security entitlements and of the qualifications of intraEU migrant workers seeking to take advantage of the basic right to freemovement to another member state had become heavily regulated.

1991-7: MAASTRICHT AND CITIZENSHIP OF THE EU

The new Treaty on European Union (TEU) agreed at Maastricht in December 1991 represented a milestone in the status of the social dimension 
(Geyer, 1996). It contained new chapters on 'Education, Vocational Training, and Youth' (Title VIII, Chapter 3) and on 'Public Health' (Title X), allowing the Commission a circumscribed new role in fostering a 'European dimension' to education while prohibiting laws to harmonize education systems. Similarly, the new mandate in public health excluded regulation of health care and systems but the Community was allowed action with regard to frontierless public health scourges such as smoking and drugs (see Randall, 2001). A reinforced Title on Social Policy was drafted, but as the UK rejected it, this draft Title, now called 'Agreement on Social Policy', became an appendix to the Maastricht Treaty instead (see Falkner, 1996; Leibfried, 2005). Yet, even this represented a gain in Community competencies, as the issue of social exclusion became a legitimate field of concern, and aspects of social legislation were facilitated by qualified majority voting (QMV) in the Council of Ministers, such as equality between men and women in employment.

In addition, the Maastricht Treaty consolidated European citizenship rights, expanding free movement beyond 'workers' and their 'dependants' to virtually all categories of persons, such as students, pensioners and jobseekers, though at first stopping short of giving EU free movers the right to access welfare provisions in other countries. From Maastricht onwards, a growing consensus around the notion of European citizenship led to numerous new rights, such as:

- the rights of free movers (intra-community migrants) to social security benefits and to access housing support schemes in other member states;

- the exportability of pensions and access to benefits in kind for the elderly (such as 'meals-on-wheels' delivered to the home, reduced entry to museums, cheaper travel, etc.);

- students' expanded choice to study at any EU university and their rights regarding fees, grants and scholarships;

- the recognition of all kinds of higher education qualifications generally;

- free movers' access to healthcare while temporarily or permanently resident in another member state.

The deeper significance was that the EU citizenship notion opened up social policy, loosening the ties that had hitherto bound it to working conditions and health and safety at work. However, the citizenship and free movement field did not necessarily involve member states in losing further prerogatives by transferring power to the supra-national level. Instead existing national social provisions were extended to more categories of citizens and Community migrants. Unlike earlier directives that had set improved crossnational standards, these measures reduced discrimination of 'foreign' EU citizens and allowed citizens more rights to free movement.

Social policy also developed in the 1992-7 period through the adoption of significant new legislation. This included directives on harmonizing and 
improving the treatment of pregnant workers (92/85/EEC); on parents taking parental leave from their jobs $(96 / 34 / \mathrm{EC})$; on part-time workers (96/34/EC); on young people in employment $(94 / 33 / \mathrm{EC})$; on the holidays and rest periods of employees (93/104/EEC); and on the right to information and consultation of employees (94/45/EC). Thereby the EU set benchmarks across all member states that brought the laggards into 'harmony' with the rest. As in the previous period, it achieved this with the aid of creative new routes for decisionmaking, such as the special Appendix to the Maastricht Treaty - a 'procedural breakthrough' (Leibfried, 2005) - and by granting European business organizations and trade unions - the 'Social Partners' - the right to reach agreements independently of the Council of Ministers, the European Parliament, or the European summits (see Regalia, 1996; Vobruba, 1995).

\section{7-2000: THE AMSTERDAM TREATY AND AFTER}

The 1997 Treaty of Amsterdam marked another milestone in the status of social policies in general, as they were bolstered by a set of civil and human rights. A declaration on the death penalty was introduced, stating that all member states rejected it. The wording on European citizenship rights was strengthened, confirming more clearly that all have the right to reside in any member state, not just workers. The status of gender equality was raised, to become a chief goal of the EU (Art. 2), and positive action to advance sex equality was allowed (Art. 141).

A new article with wide-reaching implications banned discrimination on the grounds of sex, racial or ethnic origin, religion or belief, disability, age and sexual orientation (Art. 6A, later consolidated as 13). It allowed the Community to take action to combat discrimination, albeit only via unanimity in the Council of Ministers. This marked a clear shift by the EU towards addressing issues of race and ethnicity, and by implication, the treatment of new immigrants and foreigners, something that the European Parliament had campaigned for since the 1985 Evrigenis Report on racism and xenophobia and MEP Glynn Ford's 1990 Report criticizing the Council for its inaction (Ford, 1992). Two strong directives followed, on Equal Treatment between persons irrespective of racial or ethnic origin (2000/43/EC) and Equal Treatment in employment and occupation, combating discrimination on the grounds of religion or belief, disability, age, or sexual orientation, as regards employment and occupation (2000/78/EC).

Furthermore, from then onwards the Commission was allowed to facilitate coordination of member state action in all social fields. In job creation and active labour market policies, the Commission's remit was enlarged to include the promotion of employment with a view to contributing to a 'high level of employment', previously a member state responsibility, and it was given a freer hand in taking up the defence of consumers' bealth, safety and 'economic interests' under the consumer protection Title XIV, \$. 1.

Amsterdam also introduced procedural innovations. First, Title XI (Art. 139) spelled out clearly that European-level management and labour may reach 
Agreements that can be directly sent to the Council of Ministers for adoption as Directives. Second, a new 'coordinated strategy for employment' (Art. 2) was to be launched, sustained by a set of innovatory procedures described in Article 4, which became known after the 2000 Lisbon European Council as the 'open method of coordination' (OMC), and widely judged to be a new mode of governance (e.g. Hodson and Maher, 2001; Radaelli, 2003). In brief, the European Council (heads of State and government), the Commission and the member states now act together to first exhort, then pressure member states to achieve the desired social and economic outcomes from commonly approved objectives. They take on commitments and lay themselves open to scrutiny of their ensuing actions by reporting on their achievements, and even allow other member states and the Commission to check up on their performance and comment on it publicly. This coordination procedure was immediately put into practice by a European Council decision taken in November of 1997 to issue 'Employment Guidelines' that member states must apply (European Council, 1997: \$3).

\section{0-: THE NICE SUMMIT AND BEYOND}

Given the wealth of developments since 2000, this section will highlight major innovations in keeping with the article's focus on new methods and modes of governance. These are the Charter of Fundamental Rights, the European Constitution and a further development, at the 2000 Lisbon Council, of the intergovernmental social policy convergence strategy, the OMC.

In the late 1990s, the Commission took steps to put social and civil rights on a firmer footing through a new Charter of Fundamental Rights, a broader statement than the 1989 Community Charter of Fundamental Rights of Workers that was still focused mainly on employment-related rights. An Expert Group on Fundamental Rights was charged with bringing together the EU's own established principles and rights with those enshrined in the member states' own Constitutions and legislation (Expert Group on Fundamental Rights, 1999). In December 2000, the new non-binding Charter of Fundamental Rights was adopted by the member states at the Nice summit and was later incorporated, unchanged, into the 2004 draft Treaty establishing a Constitution for Europe. The latter was ratified by 14 member states by the end of 2006. Some of the rights set out in the Charter were drafted with the intention of becoming justiciable, 'capable of being interpreted and applied by the courts' (O'Leary, 2005: 50), but others were intended to be 'programmatic' rights requiring development through policy making (O'Leary, 2005: 51). However, the European Court of Justice (ECJ) can, and may well, refer to the Charter when interpreting case law, and the European Parliament has declared that ' ... the Charter will be the law guiding the actions of the Assembly' (Fontaine, 2000, emphasis added). Indeed, the text of the European Constitution states (Art. 70) that 'The Union shall recognise the rights, freedoms and principles set out in the Charter ... '. Thus, member 
states that have approved the Constitution, particularly those with rudimentary or incipient welfare states who do not grant the Charter's rights in their national legislation, could find themselves the object of claims, but there is no clear view as to whether they would be successful.

The Charter in fact develops the existing relationships between EU member states and their citizens in political and social matters - it expands the obligations of states. Threlfall (2002) concluded that it would introduce rights not previously covered by EU legislation, such as protection against unjustified dismissal from a job (Art. 30) and in Article 28, the right to strike, previously excluded from the Community competence (European Commission, 2002). Both of these could have a considerable impact in certain old and new member states. Furthermore, the Equality chapter is significant because it acknowledges the status in EU concerns of social collectivities not linked to the labour market in a much more explicit way than in previous texts. In other words, the EU's view of its own constituents has shifted from the business and labour communities to encompassing the whole range of citizens, including the elderly, the disabled and women as women. They can all expect to gain from the Charter. For instance, it states that 'Equality between men and women must be ensured in all areas including employment, work and pay' (Art. 23, emphasis added). This arguably opens the way for the development of measures for what Guerrina (2005) discusses as substantive gender equality. The words 'in all areas' can be interpreted as including freedom from violence or the right to bodily integrity, and protection from domestic violence, rape, trafficking and sexual exploitation, as well as the right to birth control and abortion - all on the grounds that, in practice, women often can neither enjoy their freedoms nor assert practical equality unless they also have autonomy over their body (European Women's Lobby, 2001).

However, the Charter remains a 'hybrid creation' (Threlfall, 2002). On the one hand, it is selective of the social rights that it chooses to cover and does not emulate the comprehensive nature of some national Constitutions' social provisions (for example Spain's). On the other hand, it incorporates wellestablished Community rules such as free movement and residence within the $\mathrm{EU}$, workers' rights to information and consultation, together with extensive applications of the equal treatment principle - none of which are typical of national constitutions. Thus, it both falls short of and overspills the boundaries of what the average member state citizen, informed by a national perspective on her/his rights, might expect.

The new millennium also saw an expansion of social policy activity around welfare issues, but with a twist. The Lisbon European Council of 2000 fleshed out the employment policy coordination procedure set out in the Amsterdam Treaty as an 'open method of coordination' with the use of indicators and benchmarks, and required that it should be extended to all levels, starting with vocational education, skills training and social exclusion (European Council, 2000). Effectively, governments charged EU institutions with a proactive role 
in these fields, as part of modernizing the European social model and 'building an active welfare state' (\$24), a significant departure in terminology that consolidated the EU's evolving concern with social policy as it is traditionally understood. The twist lies in the word 'active' insofar as the member states were to encourage their publics into the labour market by making themselves more employable via such efforts as digital reskilling and entrepreneurship; and to alleviate tax pressures for employers of relatively unskilled and low-paid labour to increase hiring.

Since then, further social OMCs have been set up, such as on immigration policy (Chalmers and Lodge, 2003: 4), pensions and health care. Given the number of $\mathrm{OMC}$ processes in operation, it is not possible to summarize their activities and effects, not least because analysts see their purpose differently. For some they are about 'organized mutual learning' (Zeitlin, 2005: 215). On the other hand, OMCs ostensibly involve governments in trying to influence the responses of domestic social actors and to shift social trends. Initial assessments of their impact have varied considerably, even within an OMC. Social inclusion received a positive early assessment in Begg and Berghman (2002), yet Greece's own report was frank in its recognition that social inclusion had not in any way progressed in Greece (Hellenic Republic, 2005: 6). Whatever their manifest achievements or failings, they are set to continue, as, where failings have been detected, the Commission has redrawn working procedures to improve the way they function, such as in the case for employment (European Commission, 2006a) and social inclusion, for which a new framework came into operation at the end of 2006 (European Commission, 2005).

Lastly, the 2004-6 period saw a challenge to the EU's social acquis in the form of the Bolkestein proposal for a directive that would have undermined sections of the Posted Workers directive (96/71/EC) protecting the working conditions of EU workers posted to other member states. The draft Services directive originally included a 'country of origin principle', whereby businesses would be able to maintain the employment conditions of workers pertaining to their country of origin while providing services in other member states. Precisely because not all aspects of the employment relationship are covered by EU regulation, the draft directive would have given businesses from countries with worse labour conditions the chance of gaining an advantage by operating in member states with higher labour standards, profiting from the higher fees and income while paying out lower wages and in cheaper conditions. Despite this, the draft Services directive went through the Community procedure and underwent protracted negotiations and a trade union and civil society campaign (see http://www.stopbolkestein.org) between January 2004 and December 2006 before the sections that were disadvantageous to labour were removed. Article $1, \$ 6$ of the directive $(2006 / 123 / \mathrm{EC})$ now states that the directive does not affect labour law. This, significantly, was achieved through a majority vote in the European Parliament. 
This account concludes at a moment of uncertainty but of great possibility for the social dimension of the EU. The Constitution states that the EU will be devoted to the 'well-being of its citizens' (Art. 3.1), as opposed to just improving working conditions, and will aim 'at full employment and social progress'. It states that it 'shall combat social exclusion and discrimination, and shall promote social justice and protection, equality between women and men, solidarity between generations, and protection of children's rights', all based on a 'social market economy' (Art. 3.3). Children's rights are an example of yet another new field of EU concerns. If finally ratified by all members, it will establish a stronger social philosophy. A Charter of Fundamental Rights made justiciable would open the way for new rights for workers and women. The very broad new anti-discrimination laws coming into force could have enormous impact and almost a dozen cooperation processes over employment and social policies still hold quite some potential. Greater social integration of one kind or another is likely to result, as it is unlikely that all fronts will fail, though some may disappoint. Further incremental developments of an uneven kind, on a variety of policy fronts, leading to different types of social integration, are therefore to be expected.

All in all, this synthetic narrative clearly reveals the steady expansion of the Commission's and other EU institutions' competencies into more and more social areas, as well as a continual widening of the categories of citizens affected by the measures adopted, both through supra-nationalization (directives) and intergovernmentalism (charters and the OMCs). However, despite the potential for further expansion mentioned earlier, one should be wary of seeing EU social integration as a dynamo of relentless expansion, rising inexorably towards some Churchillian 'sunlit uplands'. The next section will focus on the political procedural innovation that has helped to overcome or bypass a number of obstacles to social integration.

\section{Innovative Routes through the Minefield of European Integration}

The second part of this article will focus on the plurality of methods, procedures and routes for decision-making that have been deployed in order to expand the EU's social dimension. It argues that the social facet of integration has been shaped by multi-level modes of governance that have had to be set in train in order to overcome unspecified resistance as well as specific blocking powers (Wallace, 2005: 61) and veto points and, in one case, to bypass a 'veto-playing' (see Bonoli, 2001; Tsebelis and Yanatagas, 2002) member state. Thus, a chief characteristic of the social dimension of European integration is arguably the way it has been enhanced and advanced through procedural innovation.

The méthode communautaire as set down in the founding treaties was designed to lead to the adoption of laws, particularly binding laws enforceable 
through supra-national authorities such as the court of justice. In time, over 50 significant social directives were adopted (author count), without counting the many complementary directives strengthening or clarifying aspects of the social security arrangements for free movement of workers and the health and safety of workplaces (both heavily regulated areas), and leaving out of the count those on consumer and public health protection.

But under the Community method, regulation entails upward harmonization requiring member state compliance with levels of protection and rights that may be higher than those established in their country. Directives can be viewed as burdens to industry that push up labour and business costs, for instance, in the arguments made public by the British government regarding the 1993 Working Time directive (see also Addison and Siebert, 1993). Rationales for social policy regulation have struggled to become established in the face of, on the one hand, a wide debate about competitiveness, deregulation and flexibility, and on the other, a less public discussion about the doubtful merits of trying to harmonize the social systems of the member states. This concluded by the late 1980s that harmonizing social systems was fraught with difficulties and that there was no pressing need for it (Hantrais, 1995: 23-5). Instead, member states could agree common policy objectives and work towards convergent outcomes of policies and social systems without regulation, as stated in the Council of Minister's Recommendation on the convergence of social protection objectives and policies (Council of the European Union, 1992).

In this uninviting context for regulatory policy initiatives, the deployment of four major different methods (méthodes) are considered to be politically significant as they extended the social dimension. These are: (1) drawing up general agreements over principles and values in a charter, e.g. the 1989 Community Charter of Fundamental Rights of Workers and the 2000 Charter of Fundamental Rights; (2) entering opt-out clauses and appended agreements to treaties, such as the Agreement on Social Policy and its accompanying Protocol; (3) delegating social policy decision-making to the subsubsidiary European level of labour and business, such as the European Social Partners; and (4) galvanizing member states into cooperating with each other to agree desirable policy outcomes and undertake non-legal forms of action to influence socio-economic trends in their own countries, such as the OMC processes. These are considered next.

\section{DRAFTING GENERAL AGREEMENTS OVER PRINCIPLES AND}

\section{VALUES IN CHARTERS}

In the mid-1980s, Jacques Delors, then President of the Commission, proposed the adoption of a Community Charter of Fundamental Rights of Workers as a framework to encapsulate a new consensus and allow the Commission to extend social rights beyond the workplace. This step can be seen as a manoeuvre to advance the possibility of law-making in a difficult terrain by first finding agreement on social principles, expressed as high-sounding 
moral ideals, to capture the 'moral high ground', thereby enthusing the public and governments and leaving specific commitments to later. As a tactic, this can be compared to first erecting the roof of a new building in order to justify having to fill in the wall cavities and furnish it later. It was arguably successful, as 11 of the then 12 member states adopted the 1989 Charter and later agreed to convert the principles into a revised treaty Title on Social Policy at Maastricht to strengthen their impact.

\section{THE SPECIAL TREATY APPENDIX: THE MAASTRICHT SOCIAL} AGREEMENT

When the UK objected to this new draft treaty Title on Social Policy in late 1991, 11 member states bypassed the UK by drafting a separate Social Agreement appended to the Maastricht Treaty by special Protocol that made law-making possible without UK approval in social fields even where unanimity was required. This led the way to the adoption of two new directives in previously controversial areas: the European Works Councils for the purpose of informing and consulting employees (94/45/EC), and the right to Parental Leave from work (96/34/EC) for parents of pre-school children.

This shows what can be done with the problem of dissenting minorities or 'veto players' if the political will of a large majority is strong enough. It also shows that in some countries such as the UK, European social policy represented a key divide between the major parties of the two-party system. In the absence of a national consensus, the 1997 replacement in power of the dissenting Conservatives by the pro-EU Labour party led to a sudden acceleration in regional integration. The new Labour government abolished the Protocol on the UK exception and accepted the consensus view on Europe's social dimension, which allowed the next European summit meeting on treaty revision to expand it considerably, as shown in the previous section on the Amsterdam treaty. It is worth speculating whether the development of social policy would have been definitively arrested if integrationist political actors (in the European Council and/or Commission) had not devised the complex arrangement of the Protocol and Social Agreement with its internal differentiation between social policy areas subject to unanimity and those subject to qualified majority voting.

\section{THE SOCIAL PARTNERS AGREEMENT}

This procedure is the third example of the resort to special routes for social policy-making that are arguably the hallmark of the European social integration process. Employers and trade unions have long been represented at EU level through the Union des Industries de la Communauté Européenne (UNICE) and the European Trace Union Confederation (ETUC) respectively, in addition to other business confederations. In 1985, under the leadership of the then Commissioner for Social Affairs, Vasso Papandreou, it was agreed that, since the social partners were already engaged in a 'dialogue' involving 
regular meetings, if they could reach agreement on a proposal sent to them by the Commission, such a 'Social Partner Agreement' would go forward for adoption by the Council without the Commission reformulating it.

Originally, a one-line article (118b) had been added to the 1986 Single European Act to this effect. The idea was to break the political deadlock reached over the first (1980) Draft directive on procedures for informing and consulting employees (known as the 'Vredeling' proposals) that would have required companies to set up Works Councils with union representatives on them. The Council of Ministers had refused to adopt it. Ironically, the Social Partners never managed to agree to the directive under the new route either. But the new procedure came into its own when they did unexpectedly agree a version of the Parental Leave directive that the UK had long refused to approve. This then went straight to the Council in 1995, using the Treaty Social Agreement route that bypassed the UK, and was finally adopted in 1996. In addition, the Social Partners reached agreement on 6 June 1997 on removing discrimination from, and instituting equal treatment of, Part-time Workers (97/81/EC), which was also sent to the Council for approval under the Social Agreement procedure excluding the UK. Thus in these two cases, the position of one member state, the UK, was both politically and legally undermined by an alliance of European-level non-state organizations of industry and labour even though these included representatives of UK businesses (Confederation of British Industry [CBI]) and trade unions (Trades Union Congress [TUC]).

It is worth highlighting that the new Social Partners route was first introduced by a small harmless-sounding amendment (118b) in the larger intergovernmental bargain of the Single European Act. As more recent Social Partner Agreements have shown, the procedure offers a way of working around political difficulties in the Council of Ministers, and is also used to reach binding European-wide regulation of very specific working environments, such as the Working Time of Seafarers directive (1999/63/EC) where governments would rely on expert advice as a matter of course. Evidently, if employers have agreed to the measures, this closes off political objections such as over the excessive costs of regulation. Thus, the traditional Commission and government-led méthode can alternate with a non-state actor-led method, according to political demands and specific requirements.

However, the Social Partners route had its risks since, historically, business and labour have tended to be anything but 'partners', as their failure to agree to even a watered-down version of the directive on informing and consulting employees at work showed. On this occasion, a proposed directive that upset a wide range of employers was re-routed to the other innovative method of the Social Agreement, whereby the Council of Ministers was able to adopt it (94/45/EC) without reference to the UK, under the firm hand of the German Presidency of 1994. Such procedural complexity serves to advance social integration over and behind political reluctance of various kinds. 
THE OPEN METHOD OF COORDINATION

The OMC in turn introduced another new method of operation at EU level. Arguably, the OMC gives the appearance of being intergovernmental since member states, between National Action Plans, are left to implement the policies. Yet the Commission has the power of initiative and oversight over the whole process. The OMC is often referred to as 'soft' law, as if it represented a retreat from the task of integration through 'hard' legal harmonization. Yet, Ferrera (2002: 227) noted that it had 'a strong potential of conditioning the direction of change at national level'. The point is that the Commission gained a role in employment creation (and later in the fields of social inclusion and others) - an area in which the EU cannot legislate, since no binding law can force a member state to create a minimum number of jobs or alleviate a specific number of people from living in poverty. Thus, the Commission gained a locus of intervention to help member states to shape policies designed to achieve specific socio-economic trends, rather than laws. This is arguably the key novelty of the OMC in terms of the social integration process, whether these trends move in the desired direction or not.

Four alternative policy-making methods have been highlighted and conclusions need to be drawn regarding their significance. First, these are clearly distinctive features of social policy-making that made a special contribution to advancing social integration. Second, two methods represent new routes towards a non-regulatory political consensus over the direction of policy (the Charters and the OMC), while the two others contain alternative routes to binding directives. If one looks back over the history of social policy-making, this mix of instruments is not new. Binding directives and non-binding ('soft') recommendations have been official tools since Rome, indicating that not all decisions were thought to be appropriate for supra-national enforcement even then. The involvement of non-state actors is also part of the original EU architecture - the tripartite Economic and Social Council (ESC) has an inbuilt right to consultation and to issue official Opinions, however much these can be overlooked. While the four methods studied are individually new, they are best seen as innovative in a long-standing context that allows different procedures to be essayed, or to be left underused when they do not work, as with the recommendations and the ESC. To 'work' means essentially to lead to member state behaviour that will advance integration.

Second, while the charters are non-binding agreements on principles and therefore 'soft', both the 1989 and the 2000 Charters were designed as foundations for, or stepping stones towards, binding law - the former led to no less than 16 proposals for directives. Equally, the Social Partners Agreements translate into law. Thus they signify, arguably, the continuity in the EU's legalistic, rights-based approach. This is also illustrated in the building of a fuller 'Constitutional compromise' (Moravcsik, 2005; Zeitlin, 2005), containing as much if not more regulatory potential than Delors' attempts of the mid1980s. While the OMC is not part of the regulation tradition, it is arguably 
an iteration of the exhortative 'Recommendation' instrument, with added pressure on member states not to ignore it.

Thus the innovative methods studied here, while fitting the description of new forms of governance, do not signal any historic shift by the Community towards dependence on such new forms. Furthermore, contrary to some analysts' view (e.g. Mosher and Trubeck, 2003; Rhodes, 1995; Woolfson, 2006) there has not been a fundamental shift towards 'soft' non-binding law in social policy-making. Instead, there has been an expansion of the routes used for developing policies that also lead to social integration, and they have all been deployed simultaneously and iteratively. In this sense, Community methods cannot be ranked on normative or on efficiency grounds. For what is prima facie 'better' about binding regulation if it cannot actually be drawn up for political reasons, or 'worse' about exhortative measures if they build consensus for future action? Therefore, the methods highlighted in this article must be seen as complementing each other - whether optimal in the circumstances or politically expedient.

Nonetheless procedural complexity does reflect political difficulties in advancing European social integration, and therefore underlines the role of Commission entrepreneurship and its will to overcome key political and technical obstacles to integration as and when they arise. Such entrepreneurship and commitment on the part of the Commission to its integrationist communautaire role signals a fruitful direction for future research.

\section{Conclusions}

What is most striking about the EU's social dimension is the steady growth of social fields in which the Commission has gained a role to play and the member states have agreed to Europeanize either their legal practice, their policy priorities, or their discourse and debates. This organic spreading habit has not only involved binding regulation through harmonization and approximation of laws adopted at government and European Parliament level, but also the increasing involvement of non-state actors such as representatives of business and trade unions, and to a lesser extent, women's organizations, disability and race groups, as well as experts and service providers (such as the Pensions Forum - see European Commission, 2006b).

In conclusion, this complexity, rather than being part of the problem, is part of the solution to social policy-making, as it has allowed EU penetration of previous 'no-go' zones, and has led to a strengthening of the social dimension over the long term. Such a claim amounts to a partial contestation of Moravcsik's contention that social welfare, viewed in terms of citizen-state relations, has been left 'essentially untouched' by 'direct EU policy-making', and that the 'EU policy pays a subordinate role' in social policy compared to the national state (Moravcsik, 2005: 365). In terms of EU institutions, it is 
undeniable that diverse activity on various fronts and in different modes has meant that every time the Treaty is amended, the EU's social concerns and competencies are enhanced, and never more so than in the latest revision, the Constitution, notwithstanding its uncertain political status. The EU has become more concerned with the general welfare of its citizens than it was even a decade ago, moving from the supra-national regulation of working conditions to taking responsibility for living conditions. The social protection and freedom from discrimination required to ensure a better quality of life for citizens and residents is now a fundamental mandate of the Union - even when it does not always deliver clear improvements.

\section{Issues for Other Regional Integration Processes}

The EU can be considered to have a more developed social dimension than the other regional integration organizations such as the Andean Pact. ${ }^{3}$ Some organizations may be sceptical of it, querying its function in a regional integration process. Social policy could be viewed as a luxury for developed countries with high levels of GDP, where there are substantial revenues from taxation to be redistributed. Yet, even though the EU began as a community of socio-economic near equals, every enlargement has increased internal disparity between the GDP of new and old members, and Romania and Bulgaria's membership widens the gap as never before. For the poorer countries, membership of a richer EU is socially beneficial when it can export labour, produce and export cheaper goods, and benefit from cohesion policies as strong as the EU's Structural Funds. In such a context, social policy becomes a development tool supporting inter-country economic and social catch up - such as in the cases of the Irish Republic, currently the richest country in the EU in terms of purchasing power standards (Eurostat, 2005) - and Spain. Meanwhile, strict competition policies in the EU single market, regulation of product standards and the treatment of employees all serve to reassure the richer states by preventing the 'distortion' of competition and 'social dumping', whether real or feared, and to pressure the less-developed members to push standards up.

In order to have a meaningful discussion over the role of social policy in integration processes, the EU experience shows that it is essential to define it broadly as done here. It is also crucial to take into account the activities of all the institutions involved both in an official capacity and less formally, whether legal, politico-bureaucratic, politico-representative, or belonging to civil society, as they tend to be engaged in different but complementary activities. In addition, evaluations of 'progress' need to distinguish between: (1) progress in pooling sovereignty (decision-making) among nations; (2) progress in adopting common policies through cooperation without supra-national regulation; and (3) progress in creating single social areas (Threlfall, 2003) in terms of removing internal barriers so that only the outer boundaries of the region 
remain significant to the citizens' experience of living and working within it. These can all claim to be part of 'europeanization'. Thus, while the welfare provider role of the EU remains non-existent and member states are free to debate social spending priorities in domestic fora, they are, nonetheless, not free to take an increasing number of actions, such as refuse maternity leave and pay to mothers, employ child labour, or refuse social security entitlements to a wide range of their residents, to mention just a few examples.

Furthermore, it is key for other regional integration processes to recognize just how much power has been handed to the EU institutions, both to push ahead with decisions and to implement them. There is the Commission's key right of legislative initiative to bring proposals forward; its independence from the Council of Ministers (since it is not its civil service, but that of a supranational entity); the mandate of the European Court of Justice and its integrationist conception of its role; and the mechanisms by which the institutions exercise forms of surveillance and monitoring of member states over their implementation of agreed directives via the Reports of the Application of Community Law (European Commission, 2006c; EU Scadplus Europa Glossary), together with the power of taking infringement proceedings against member states, and of inflicting economic sanctions on them for non-compliance. This regulatory power provides essential solidity to the decisions taken.

Finally, different fields of social policy need different treatment. Some are suitable for regulation, others not. Certain member states may be attached to their welfare systems, traditions and political visions of what constitutes the good society more than others. The lack of uniformity in the measures taken to advance social integration is a flexible response to that, and need not be perceived as a weakness. Instead, different approaches, call them methods, procedures or routes, are a political strength in dealing with equivocation or dissent. Thus, in the EU, member state governments have been able to combine the autonomy they still enjoy over areas of social policy with the advantages brought by burden-sharing, policy-learning and gradual convergence of policy outcomes, particularly in cases where the harmonization of social protection systems or approximation of laws are viewed as problematic.

All in all, the EU provides a major and positive global example of the ways in which transnational regulation and upward harmonization of social policies, standards and rights, together with regional redistribution, can become institutionalized, especially when member states have allowed the centripetal pull of supra-national lawmaking bodies to take its course.

\section{ACKNOWLEDGMENT}

Thanks are due to UNESCO social \& Human Sciences Division and MERCOSUR for hosting and funding travel to present the earlier version of this article at the High Level Symposium on The Social Policy Dimension of Regional Integration: Research and Policy Perspectives, Montevideo, 18-20 February 2006; and to three anonymous referees for their very useful comments. 


\section{NOTES}

1. In this article the popular terms 'soft' and 'hard' are avoided for the sake of precision, and replaced with 'exhortative' and 'binding'.

2. While acknowledging the extensive impact of the European Court of Justice in social fields (see Kenner, 2003; O'Leary, 2005; Shaw, 2000) it is not possible to include its jurisprudence in this account of the social acquis.

3. The Andean Pact has taken only broad decisions on socio-labour matters, mainly health and safety of workers. It only adopted a Social Development Plan in 2004 (Decision 601) and began discussions on launching a social fund in 2005. See http://www.comunidadandina.org/normativa.htm

\section{REFERENCES}

Addison, J.T. and Siebert, S. (1993) Social Engineering in the European Community: The Social Charter, Maastricht and Beyond. London: Institute of Economic Affairs.

Begg, I. and Berghman, J. (2002) 'Introduction: EU Social (Exclusion) Policy Revisited', Fournal of European Social Policy 12(3): 179-94.

Bonoli, G. (2001) 'Political Institutions, Veto Points, and the Process of Welfare State', in P. Pierson (ed.) The New Politics of the Welfare State (pp. 238-64). Oxford: Oxford University Press.

Chalmers, D. and Lodge, M. (2003) 'The Open Method of Coordination and the European Welfare State', Paper No. 11, ESRC Centre for Analysis of Risk and Regulation, London School of Economics and Political Science.

Charter of Fundamental Rights of the European Union, Official Journal of the European Communities C 364 18.12.2000, accessed February 2001, http://europa.eu.int/comm/justice_home/unit/charte/index_en.html

Commission of the EC (1989) 'Medium-Term Community Action Programme to Foster the Economic and Social Integration of the Least Privileged Groups', Bulletin of the EC, Supplement 4/89, 33 pp.

Council of the European Union (1992) Council Recommendation on the Convergence of Social Protection Objectives and Policies of 27 July 1992 (92/442/EEC).

De Búrca, G. (2005) EU Law and the Welfare State: In Search of Solidarity. Oxford: Oxford University Press.

European Commission (2002) Charter of Fundamental Rights, accessed 13 January 2002, http://europa.eu.int/scadplus/leg/en/cha/c10101.htm

European Commission (2005) 'Working Together, Working Better: A New Framework for the Open Coordination of Social Protection and Inclusion Policies in the European Union', Communication, COM (2005) 706 final, accessed 10 August 2006, http:// ec.europa.eu/employment_social/social_inclusion/docs/com_2005_706_en.pdf

European Commission (2006a) 'Social Protection in the EU', webpage information, 'Pensions', accessed 3 February 2006, http://ec.europa.eu/employment_social/ social_protection/pensions_en.htm

European Commission (2006b) 'The European Employment Strategy', webpage information, accessed 6 February 2006, http://europa.eu.int/comm/employment_ social/employment_strategy/index_en.htm

European Commission (2006c) Scadplus Europa Glossary, accessed 6 February 2007, http://europa.eu/scadplus/glossary/community_law_application_en.htm

European Council (1997) 'Presidency Conclusions' of the Extraordinary European Council Meeting on Employment', Luxembourg, 20-1 November, last accessed 23 January 2007, http://ue.eu.int/en/Info/eurocouncil/index.htm 
European Council (2000) 'Presidency Conclusions' of the European Council of 23-4 March, Lisbon, accessed 31 November 2004, http://www.consilium.europa.eu/ ueDocs/cms_Data/docs/pressData/en/ec/00100-r1.en0.htm

European Parliament British Labour Group (1989) The Social Charter: How Britain Benefits, pamphlet. London: Labour Party.

European Parliament and Council (1996) Directive 96/71/EC Concerning the Posting of Workers in the Framework of the Provision of Services, Official Journal L 018, 21/01/1997 (pp. 0001-0006).

European Parliament and Council (2006) Directive 2006/123/EC on Services in the Internal Market, Official Journal L376 (pp. 36-68).

European Women's Lobby (2001) 'EWL position on the Charter of Fundamental Rights of the EU', policy document, accessed 9 August 2006, http://www.womenlobby.org/site/1abstract.asp? DocID=235\&v1ID=\&RevID=\&namePage =\&pagePa rent $=\&$ DocID_sousmenu $=\&$ parentCat $=18$

Eurostat (2005) 'Table: GDP per inhabitant in PPS, 2005', accessed 9 August 2006, http://europa.eu/abc/keyfigures/qualityoflife/wealthy/index_en.htm

Evrigenis, D. (1985) Report of the Committee of Enquiry into the Rise of Racism and Xenophobia in Europe. Luxembourg: European Parliament.

Expert Group on Fundamental Rights (1999) Affirming Fundamental Rights in the EU, report. Luxembourg: OOPEC.

Falkner, G. (1996) 'The Maastricht Protocol on Social Policy: Theory and Practice', Fournal of European Social Policy 6(1): 1-16.

Falkner, G. (1998) 'Eu Social Policy in the 1990s: Towards a Corporatist Policy Community'. London and New York: Routledge.

Ferrera, M. (2002) 'Open Coordination Against Poverty: The New EU Social Inclusion Process', Fournal of European Social Policy 12(3): 227-39.

Fontaine, N. (2000) 'Statement by the President of the European Parliament, Nicole Fontaine on signing and proclaiming the Charter, 7 December 2000', extract, accessed 6 February 2007, http://www.europarl.europa.eu/charter/default_en. htm\#declarations

Ford, G. (1992) Fascist Europe: The Rise of Racism and Xenophobia. London: Pluto Press.

Geyer, R. (1996) 'EU Social Policy in the 1990s: Does Maastricht Matter?', Fournal of European Integration 20(1): 5-33.

Geyer, R. (2000) Exploring European Social Policy. Cambridge: Polity Press.

Goetschy, J. (2002) 'The European Employment Strategy, Multi-Level Governance and Policy Coordination: Past, Present and Future', in J. Zeitlin and D. Trubeck (eds) Governing Work and Welfare (pp. 59-87). Oxford: Oxford University Press.

Grahl, J. and Teague, P. (1992) Industrial Relations and European Integration. London: Lawrence and Wishart.

Guerrina, R. (2005) Mothering the Union: Gender Politics in the EU. Manchester: Manchester University Press.

Hantrais, L. (2000 2nd ed.) Social Policy in the European Union. Basingstoke: Macmillan Press. Hellenic Republic (2005) Ministry of Employment and Social Protection, National Action Plan for Social Inclusion, accessed 16 January 2006, http://europa.eu.int/comm/ employment_social/social_inclusion/docs/2005/el_en.pdf

Hodson, D. and Maher, I. (2001) 'The New Open Method as a new Mode of Governance: The Case of "Soft" Economic Policy Coordination', Fournal of Common Market Studies 39(4): 719-46.

Hoskyns, C. (1996) Integrating Gender: Women, Law and Politics in the European Union. London: Verso. 
Hughes, J. (1991) The Social Charter and the Single European Market. London: Spokesman. Kenner, J. (2003) EU Employment Law: From Rome to Amsterdam and Beyond. Oxford: Hart. Kleinman, M. (2002) A European Welfare State? Basingstoke: Palgrave.

Labour Research Department (1989) The Social Charter Thatcher Left Bebind, Briefing Document.

Leibfried, S. (2005) 'Social Policy: Left to the Judges and the Markets?', in W. Wallace, H. Wallace and M. Pollack (eds) Policy-Making in the European Union, 5th edn (pp. 243-78). Oxford: Oxford University Press.

Leibfried, S. and Pierson, P. (eds) (1995) European Social Policy: Between Fragmentation and Integration. Washington, DC: Brookings Institution.

Moravcsik, A. (2005) 'The European Constitutional Compromise and the Neofunctionalist Legacy', Fournal of European Public Policy 12(2): 349-86.

Mosher, J. and Trubeck, D. (2003) 'Alternative Approaches to Governance in the EU: EU Social Policy and the European Employment Strategy', Fournal of Common Market Studies 41(1): 63-88.

O'Leary, S. (2005) 'Solidarity and Citizenship Rights in the Charter of Fundamental Rights of the EU', in G. de Búrça (ed.) EU Law and the Welfare State: In Search of Solidarity (pp. 37-87). Oxford: Oxford University Press.

Radaelli, C. (2003) The Open Method of Coordination: A New Governance Architecture for the European Union? Stockholm: Swedish Institute for European Policy Studies, accessed 14 February 2006, http://www.sieps.se/publ/rapporter/2003/2003 1_en.html

Randall, E. (2001) The European Union and Health Policy. Basingstoke: Palgrave.

Regalia, I. (1996) 'How the Social Partners View Direct Participation', European Fournal of Industrial Relations 2(2): 211-34.

Rhodes, M. (1995) 'A Regulatory Conundrum: Industrial Relations and the Social Dimension', in S. Leibfried and P. Pierson (eds) European Social Policy: Between Fragmentation and Integration (pp. 78-122). Washington, DC: Brookings Institution.

Ross, G. (1995) 'Assessing the Delors Era and Social Policy', in S. Leibfried and P. Pierson (eds) European Social Policy: Between Fragmentation and Integration (pp. 357-88). Washington, DC: Brookings Institution.

Shanks, M. (1977) European Social Policy: Today and Tomorrow. Pergamon Press.

Shaw, J. (ed.) (2000) Social Law and Policy in an Evolving European Union. Oxford and Portland, OR: Hart Publishing.

Threlfall, M. (2002) 'The European Union's Social Policy: From Labour to Welfare and Constitutionalised Rights?', in R. Sykes, C. Bochel and N. Ellison (eds) Social Policy Review 14 (pp. 171-94). Bristol: Policy Press.

Threlfall, M. (2003) 'European Social Integration: Harmonization, Convergence, and Single Social Areas', Fournal of European Social Policy 13(2): 121-39.

Tsebelis, G. and Yataganas, X.A. (2002) 'Veto Players and Decision-Making in the EU after Nice: Legislative Gridlock and Bureaucratic/Judicial Discretion', Fournal of Common Market Studies 40(2): 283-307.

Vobruba G. (1995) 'Social Policy on Tomorrow's Euro-Corporatist Stage', Fournal of European Social Policy 5(4): 303-15.

Vobruba, G. (2005) 'The Irreversible Welfare State within the Globalisation Dilemma', in B. Cantillon and I. Marx (eds) International Cooperation in Social Security: How to Cope with Globalisation? (pp. 81-91). Antwerp and Oxford: Intersentia.

Wallace, H. (2005) 'An Institutional Anatomy and Five Policy Modes', in W. Wallace, H. Wallace and M. Pollack (eds) Policy-Making in the European Union, 5th edn (pp. 49-90). Oxford: Oxford University Press. 
Woolfson, C. (2006) 'Working Environment and "Soft Law" in the Post-Communist New Member-States', Journal of Common Market Studies 44(1): 195-215.

Yeates, N. (2001) Globalisation and Social Policy. London: Sage.

Yeates, N. (2002) 'Globalization and Social Policy: From Global Neoliberal Hegemony to Global Political Pluralism', Global Social Policy 2(1): 69-91.

Yeates, N. and Deacon, B. (2006) 'Globalism, Regionalism and Social Policy: Framing the Debate', Policy Briefing Paper No. 1, High-Level Symposium on the Social Dimensions of Regionalism, Montevideo, Uruguay, 21-3 February.

Zeitlin, J. (2005) 'Social Europe and Experimentalist Governance: Towards a New Constitutional Compromise?', in G. De Búrca (ed.) EU Law and the Welfare State: In Search of Solidarity (pp. 213-41). Oxford: Oxford University Press.

RÉS UMÉ

\section{La Dimension Sociale de l'Union Européenne: Des Méthodes Innovatrices pour l'Avancement de l'Intégration}

Les processus d'intégration régionale peuvent apprendre des particularités de la dimension sociale de l'Union Européenne, malgré ses inconsistances et la forme sui generis de son développement. Cet article fourni une vue d'ensemble des développements d'une manière compréhensive et rétrospective, en tenant compte particulièrement des procédures politiques et techniques qui ont été adoptés pour faire avancer la politique sociale. L'auteur raisonne que le processus d'intégration régionale dans un vaste champ de domaines sociaux a été développé dans la UE malgré que l'UE a du faire face á des dissentiments et des dilemmes pendant plus que cinquante ans. L'auteur considère que L'UE jouisse maintenant d'un mode d'opération et d'un dispositif réalisable de politiques, pratiques et lois dans une dimension sociale vaste, qui sont non seulement plus important que ceux envisagés dans le Traité de Rome, mais qui sont aussi destinés de s'étendre davantage. En particulier, cet article s'étend au-delà des comptes précédents, en raisonnant que la complexité des procédures a été une partie intrinsèque et créative de la dimension sociale de l'intégration européenne.

RESUMEN

\section{La Dimensión Social de la Union Europea: Métodos Innovadores para el Progreso de la Integración}

A pesar de sus aparentes inconsistencias y de su forma de desarrollo sui generis, los procesos de integración regionales pueden aprender mucho de las particularidades de la dimensión social de la Unión Europea. Este artículo ofrece una visión general retrospectiva de dichos desarrollos poniendo especial énfasis en los procedimientos políticos y técnicos adoptados para hacer progresar la política social. Su autora sostiene que, a pesar de tener que hacer frente a numerosas discrepancias y dilemas durante cincuenta años, la Unión Europea ha desarrollado un proceso de integración regional en un amplio número de campos sociales. También sostiene que la UE dispone de un eficiente aparato de políticas, prácticas y leyes con una dimensión social, aparato que no solamente es más extenso de lo que estaba previsto en el Tratado de Roma, sino que 
también presenta numerosas posibilidades de expansión. En particular, este artículo pretende ir mas allá de otros trabajos previos argumentando que la complejidad de los procedimientos ha sido una parte intrínseca y creativa de la dimensión social de la integración en Europa.

BIOGRAPHICAL NOTE

monica threlfall is Senior Lecturer in Politics at Loughborough University (Loughborough, UK). The EU's social dimension is one of her main research interests and she has published on its historical development; on EU social integration, harmonization and single social areas; on European employment strategies and trends, and the work-life balance problem. She has critiqued interpretations of unemployment rates for distorting perceptions of the European social model. She is currently engaged on an EU-funded 10-country team project on Gendered Citizenship in a Multicultural Europe, leading the work on political citizenship. She has also published widely on gender issues, particularly women's movements and gender parity representation in Spain. Recent examples include 'Explaining Gender Parity Representation in Spain: The Internal Dynamics of Parties' (West European Politics, 2007); Gendering Spanish Democracy (Routledge, 2005), as main author with Christine Cousins and CeliaValiente. Please address correspondence to: Monica Threlfall, Loughborough University, Loughborough LE11 3TU, UK. [email: M.Threlfall@lboro.ac.uk] 